\title{
Multiple Homes and Parallel Civil Societies: Refugee Diasporas and Transnationalism
}

\author{
R. Cheran
}

A sylum seekers and refugees have been key players in the making of diasporas and transnational communities. The human rights approach to asylum seekers and refugees which appeared to be the hall mark of western states during the cold war era has disappeared. This "disappearance" has been clearly marked particularly in the aftermath of $9 / 11$. Asylum is now increasingly perceived through the lens of migration and security issues. A pervasive national security oriented discourse advances the sacrifice of fundamental rights and freedoms not only for local populations but very systematically and effectively for refugees, asylum seekers and other migrants. Border controls, confinement and encampment of refugees, interdiction policies, "destitution as a threat to asylum seekers" and deportation are all mechanisms by which North America and "Fortress Europe", steadfastly attempt to prevent refugees and asylum seekers from reaching their shores.

These special issues of Refuge, the current one and the following one, dealing with refugee diasporas and transnationalism, are being published in this context. ${ }^{1}$ Transnationalism as a phenomenon incorporates the economic, cultural and political practices of migrants, including refugees, who traverse several national borders. The terms diaspora and transnational have simultaneously become metaphors and categories that include various communities of displaced people, circulating migrants and people in limbo. While theorizing diaspora has a longer history, the "displacement" of the study of diaspora from history to area studies, cultural and literary studies and geography is relatively new. The conflation of studies in diaspora and transnationalism in the past decade has a symbolic representation in the title of a journal: "Diaspora: A Journal of Transnational Studies". While this conflation opens up new and challenging areas for research enquiry, it also creates some conceptual confusion and at times, uncritical interchangeability of diaspora and the transnational in a simplified manner.
The proliferation of diasporic categories such as "labour diaspora", "asylum diaspora", "victim diaspora", "feminist diaspora", "military diaspora" and "refugee diasporas" underscores a crucial element in the nature of the diaspora: ambiguity. However, we need to be cautious in not eliminating the historical specificity of these diasporas. While there is certainly a convergence between diaspora and transnational communities, it is critically important to maintain a conceptual and analytical distinction between them. The term diaspora has historically been used to describe the experience of forced displacement and to analyze the social, cultural and political formations that result from this forced displacement. Transnational communities can be generally defined as communities living or belonging to more than one "national" space. The condition of forced migration is not necessarily a component of transnational communities. However, the distinction between diaspora and transnational is not always clear in social science literature. While some scholars have argued in favor of identifying a closed set of attributes and have been only minimally concerned with the actual conditions of diasporic existence, ${ }^{2}$ others have preferred to use the term in the broader sense of human dispersal. ${ }^{3}$

The traditional naming and meaning of diasporas can be expanded to include several communities that express new identities and cultural practices as the result of displacement, hybridity and transnationality and mediated through economic transnationalism in the context of globalization. While recognizing that diasporas can eventually evolve into powerful transnational communities, it is sufficient to say that multiple and simultaneous ways of belonging and multiple ways of incorporation in the "home" and "host" countries is the one key theme that is common for both. This is the most important theme that animates the dynamics of transnational groups in the contemporary age. In that sense the traditional categories of "home" and "host" lands in the context of migration and diasporas are becoming somewhat out dated. The plurality of experiences and plurality 
of contexts and locations contribute to the formation of multiple homes and multiple locations for transnational and diaspora groups.

In order to understand and study the transnational, social, cultural and economic and political practices of these groups, the traditional paradigms of immigration/settlement/adaptation/ integration are inadequate. New analytic lenses are essential to understand the social and political processes that transcend traditional state boundaries and create transnationalism. The concept of diaspora and transnational practices and engagements question the notion of integration and assimilation within a particular national frame of "host" societies.

The traditional sociological model of immigrant assimilation is based on the process by which an immigrant group adopts the way of life, patterns of culture and other practices by the dominant, majority group. ${ }^{4}$ A critical body of recent work suggests that the notion of segmented assimilation would be a better tool in the study of these groups. ${ }^{5}$ One of the important insights offered by the proponents of the segmented assimilation model is the steady stream of new immigrants from various minority ethnic groups allow them to maintain their distinctive identities in a much stronger way than their older generations. The differential treatment of ethnic and racialized minorities and systemic racism are realities that continue to challenge "assimilation".

It can be argued that transnational practices or transnationalism have become a major force and a paradigm shift challenging traditional notions of assimilation and segmented assimilation. This paradigm shift also necessitates a critical look at the ways in which durable solutions for refugees are conceptualized, programmed and implemented. Traditionally repatriation, resettlement, and integration have been practices accepted and promoted by UNHCR, national governments and NGOs. ${ }^{6}$ However, as Van Hear notes in his article in this issue, the transnational character and practices of refugee diasporas have important implications for policy and practice in relation to the traditional triumvirates of durable solutions. For refugee receiving states and the UNHCR, repatriation is increasingly characterized as the most desirable of so called durable solutions. This view is predicated upon notions of refugee diasporas with unalterable territorial identities, loyalties and nostalgia. However, the contemporary transnational practices of refugee diasporas are multifaceted, fluid and exhibit multiple belongings and multiple homes. The key assumption that refugees will have eternal and unchanging ties to their country of origin and "home" is contested by transnationalism. The evolving complexity of networks and transnational practices increasingly challenge the idea of a society firmly perched upon the nation-state.

The countries from which these immigrant groups or "transnationals" originated ("homelands") —and the countries that the transnationals often inhabit- "host lands" - can be understood as a single field. ${ }^{7}$ Conceptualizing those who leave and those who remain as a single socio-economic and political field can be helpful in explaining transnational practices. The notion of transnational spaces is the preferred concept of some scholars to describe transnational networks and practices. ${ }^{8}$

Transnational practices - including fostering nationalism in their "homelands" by some communities-pave the way for the creation of a complex niche in the "host lands". The existence of this complex niche requires us to focus more closely on the processes, practices, actors and networks that are instrumental in structuring and organizing transnational social fields. This complex niche can be conceptually described in terms of parallel civil societies. The idea of parallel civil societies opens up new ways of thinking about "home", migration, homeland politics and/or nationalism and transnationalism. The formation and continuation of parallel civil societies in the major metropolitan cities in the West is the result of several factors. First, transnational practices that question "home" as a fixed entity in the context of refugee and other diasporas. Home in this context becomes multi-sited and extends beyond national boundaries. Secondly, the nature and impact of immigration, refugee and settlement policies of the countries in the North. These policies, together with racism and social exclusion have led to transnational practices that can be read as a response to marginalization and exclusion. Denise Spitzer in her article examines how the Canadian government policy and public discourse have operated to strengthen and maintain the liminal status of Somali women refugees. ${ }^{9}$ She points out that these policies and regulations hindered the ability of Somali women refugees to meaningfully integrate into Canadian society. Thirdly, in countries such as Canada, official multicultural policies and their impact on ethno-cultural minorities. The official policy of multiculturalism and the subsequent programs to foster multiculturalism in Canada came into existence in the 1970s. These policies facilitated a certain degree of affirmation of cultural difference while at the same time managing and channeling it through approved government avenues such as government support for ethnic and other immigrant organizations, cultural festivals, and the socalled "heritage language" programmes. In essence, the official multicultural policy is not more than a culturalist rendition of multiculturalism without corresponding political representation or power. ${ }^{10}$ 
The conceptual framework for these two issues of Refuge grew out of the conviction that transnationalism has become a dominant practice of our times and refugee diasporas signify a unique dimension in the arena of transnational practices.

The articles included in these two issues of Refuge address various dimensions and realities of the transnational practices of refugee diasporas in the international context. In addition to documenting some practices of parallel civil societies, the other important contribution of these two issues lies in the fact that several articles transcend the usual geographical bias that exists in transnational studies. Most of the literature on transnationalism is focused on the receiving context of the West while excluding countries in the South that receive large refugee populations. These two issues attempt to rectify this lacuna. However, it would not be inappropriate to say that more research is needed in this crucial area.

There are a total of twenty one articles in the two issues. Hyndman and Sherrell's article discusses the quality and distinctiveness of transnational links among Kosovars. They demonstrate that settlement and integration in contemporary world cannot be understood without consideration of transnational ties and practices. Echoing one of the main themes of the two issues, Nicholas Van Hear argues that durable solutions for refugees perhaps lie in their transnational relations and practices. He offers a simple schema for understanding diasporas and transnational relations and suggests that "transnationalism might be considered in itself as an "enduring" if not a "durable" solution to displacement."

The articles authored by Shotte, Kirk and Purveys illustrate the difficulties and barriers for adaptation that exist and how issues of identity and transnational practices are gaining more importance in the study of refugee diasporas. Bose's article on the Hindu Bengali displacement from Bangladesh critically interrogates the idea of refugee diasporas. He highlights the problems in identifying refugee diasporas as monolithic entities without any class, gender, caste and religious specificities. Pilkington and Flynn in their article deal with one of the most contentious aspects of transnationalism: the politics of "homeland". While these articles focus on different geographical regions, the key themes that underlie both articles are not only similar but point to the increasing relevance of "homeland" politics in the study of transnational political practices.

Joan Simalchik's article on the Material Culture of Chilean Exiles, approaches homeland politics and exile from a different angle. ${ }^{11}$ While pointing out how Chilean exiles managed to construct an "embodied site of struggle" through their resistance, solidarity strategies and commemorative practices, Simalchik explains how "Chileans created and inhabited a newly devised distinct space". This distinct transnational space created not only through trans- national practices but also through memory, commemoration and articulation of struggle. As she asserts, "with their emphasis on solidarity practices, [Chilean] exiles were able to create an expanse both to contain memory and to produce opposition to the military dictatorship."

Da Lomba's paper critically evaluates European Union's current asylum policy and the use of destitution as a deterrent against asylum seekers and refugees. Her article strongly makes the case that there is a gap exists between the EU asylum agenda and the EU member states' obligation under international refugee and human rights law. Neuman documents the complicity of UNHCR in the Australian government's unethical treatment of West Papuan refugees. The article explores the relations between the UNHCR and the government of Australia and argues that the UNHCR's role in providing and lobbying for protection for refugees was compromised by its consideration for Australian government's interests. This article adds an important resource to a growing body of literature that critiques the UNHCR's role in refugee protection. ${ }^{12}$

The use of internet technologies by diaspora groups and the creation of cyberspace as a unique location for effective transnational practices still remain an under researched area. Horst discusses the value of electronic media as an important methodological tool in studying transnational practices of Somali refugee diaspora.

Also included in this issue are highlights of discussions of transnationalism and forced migrants at the $9^{\text {th }}$ conference of the International Association for the Study of Forced Migration held at Sao Paulo, in Brazil in January 2005. Collyer's summary reinforces the major theme of our special issues: transnational perspectives need to be incorporated not only in the study of refugee diasporas and forced migration but they can provide significant policy interventions.

In the second issue, articles by Anna Lindley and Dianna Shandy focus on one of the important aspects of transnational practices: financial remittances. Katharya Um's study on Cambodian transnational political remittance in the post-conflict situation helps us to understand the nature and impact of political remittances as important transnational practice in conflict and post-conflict zones. Denize Spitzer and Mehrunnisa Ahmad Ali critique Canadian government policy in relation to refugee women and unaccompanied children seeking refuge. Ali's article highlights the ambiguities in the identification, case processing, care and protection of separated children in Canada and calls for a systematic study of government policies and practices.

Savitri Taylor's article considers Australia's treatment of stateless Palestinian asylum seekers and discusses whether that treatment is line with Australia's legal and/or moral 
obligations towards asylum seekers and refugees. Her disappointing conclusion is that it does not.

Fethi Mansouri's paper addresses the important issue of the psychological impact of liminality. The Temporary Protection Visa (TPV) granted to asylum seekers in Australia who arrived without valid documents but are subsequently found to be refugees. Past trauma and persecution which are not uncommon for refugees, combined with family separation, exclusionary policies advocated by the Australian government and uncertainty about future results in chronic states of anxiety and depression among TVP holders.

Susan Banki's paper discusses refugee participation in transnational acts. While there seems to be a consensus that the legal status of refugees improves the ability to engage in political transformation Banki's paper on Burmese refugees living in Japan reveals that the provision of legal status can have the opposite effect, weakening fragile community structures, stemming advocacy efforts, and discouraging communication between divided political and ethnic groups.

Read collectively the articles in these two issues broadly indicate the coordinates of important transnational practices and the consequent emergence of parallel civil societies in the metropolitan West. They are financial and political remittances, difficulties in integration in the "host countries", homeland politics, the emergence of powerful social, political and cultural networks and virtual diasporas. More research is necessary to map parallel civil societies and the transnational practices that strengthen these parallel civil societies. Some of the key areas that need closer study include the proliferation of ethnic markets, the emergence of separate media and entertainment industries outside the mainstream as well as how nationalism in the homelands is fostered through transnational diaspora practices and the impact of these practices upon conditions of war and peace.

In the discourse of terrorism that has predominated post 9/11, diaspora and transnational communities are often portrayed as supporting violence directly and indirectly through financial and political remittance. This myopic view fails to address the significant contributions of diaspora and transnational communities to peace building in the global South. ${ }^{13}$

It is highly unlikely that the majority of individuals that inhabit transnational spaces will return to their place of origin on a permanent basis. The most probable scenario is that they will circulate if/when conditions are conducive for such circulation. The idea and practice of circulation together with the degree of social capital that a transnational community possesses can have enormous impacts upon the creation of parallel civil societies and expansion of transnational spaces.
Instead of perceiving transnational communities and refugee diasporas as "others" and inherently suspicious and troublesome, governments need to find creative and effective ways to understand and learn from them. That is, perhaps, the only way to place rights, freedom and human security at the centre stage.

\section{Notes}

1. Volume 23, Issues 1 and 2 of Refuge.

2. Robin Cohen Global Diasporas: An Introduction (Seattle: University of Washington Press, 1997)

3. William Safran "Diasporas in Modern Societies: Myths of Homeland and Return" Diaspora 1:1, pp. 83-99 and Jana Evans Braziel and Anita Mannur Theorizing Diaspora (Oxford: Blackwell, 2003).

4. R.E. Park was an important early exponent in delineating this process by suggesting the four stages: contact, compettion, accommodation, and assimilation. See R. E. Park Race and Culture (Glencoe, IL: Free Press, 1950).

5. A. Portes and M. Zhou "The Segmented Assimilation and its Variants" in Annals of the American Academy of Political and Social Sciences, 530:74-96 (1993) and R. G. Rumbaut "Assimilation and Its Discontents: Ironies and Paradoxes." in C.Hirschman, P.Kasinitz and J.DeWind, eds. The Handbook of International Migration: The American Experience (New York: Russell Sage Foundation, 1999) at 172-195.

6. See generally, UNHCR The State of the World Refugees 1995: In Search of Solutions (Oxford: Oxford University Press, 1995).

7. Peggy Levitt and Nina Glick Schiller "Transnational Perspectives on Migration: Conceptualizing Simultaneity" (Princeton: Princeton University Center for Migration and Development Working Paper 3-09J, 2003) (available online at $<$ http://www.peggylevitt.org/>; last accessed 10 January 2006).

8. Ludger Pries Migration and Transnational Social Spacse (Aldershot: Ashgate, 1999) and Thomas Faist The Volume and Dynamics of International Migration and Transnational Social Spaces (Oxford: Clarendon Press, 1999).

9. Denise Spitzer's article appears in Volume 23, issue 2.

10. For a critical review of Canadian multiculturalism see, Himani Bannerji The Dark side of the Nation: Multiculturalism and Nationalism in Canada (Toronto: Women's Press, 2002) and Yasmeen Abu-Laban and Christina Gabriel Selling Diversity: immigration, multiculturalism, employment equity, and globalization (Peterborough, Ontario: Broadview Press, 2002).

11. Joan Simalchik's article appears in Volume 23, issue 2.

12. Guglielmo Verdirame and Barbara Harrell-Bond Rights in Exile: Janus-Faced Humanitarianism (New York: Berghahn Books, 2005).

13. Wolfram Zunzer, "Diaspora Communities and Civil Conflict Transformation, Berghof Occasional Paper No. 26”, (Berlin: Berghof Research Centre for Constructive Conflict Management, 2004). 
The guest editors for Refuge issues 25.1 and 25.2 are $R$. Cheran and Wolfram Zunzer.

Rudhramoorthy Cheran is an assistant professor in the Department of Sociology and Anthropology, University of Windsor, Canada. Prior to his current position, Cheran was a SSHRC Post-Doctoral Fellow associated with York University's Centre for Refugee Studies. From 1984-1992, Cheran was a working journalist in Sri Lanka where he was the editor and regular columnist for a biweekly newspaper that focused on human rights reporting in the context of Sri Lanka's civil war. Since 1990, Cheran has been a senior research consultant with the International Centre for Ethnic Studies in Colombo, where he continues to lead numerous interdisciplinary research projects on nationalism and ethnic conflict.

Wolfram Zunzer is a Programme Coordinator at the Berghof Foundation for Peace Support, Berlin. From 2001-2003, he worked for the Resource Network for Conflict Studies and
Transformation in Sri Lanka, focussing on the nexus of development aid and conflict transformation, power sharing models, and peace and conflict impact assessment. He has worked extensively on the role of diasporas in conflict transformation, and on questions of co-ordination and co-operation in peace processes. He is currently involved in research projects on "systemic" peacebuilding approaches and the role of "nonstate armed groups" in peace processes. He holds a BA in Information Science, and an MA in Political Science from the Free University of Berlin.

Further information about the Berghof Foundation for Peace Support and Berghof Center for Contructive Conflict Management is available at <http://www.berghof-peacesupport.org $>$ and <http://www.berghof-center.org $>$. Information about the Berghof Foundation for Conflict Studies, Sri Lanka Office is available at <http://www.berghof-foundation.lk>.

(C) R. Cheran, 2006. This open-access work is licensed under a Creative Commons Attribution-NonCommercial 4.0 International License, which permits use, reproduction and distribution in any medium for non-commercial purposes, provided the original author(s) are credited and the original publication in Refuge: Canada's Journal on Refugees is cited. 